\title{
Comparative Nutritional Studies of Pythium spp.
}

\author{
By P. G. FOTHERGILL \\ Botany Department, King's College, Newcastle upon Tyne \\ AND D. HIDE \\ Bacteriology Department, Division of Chemotherapy, May and Baker Limited, \\ Dagenham, Essex
}

(Received 29 January 1962)

\begin{abstract}
SUMMARY
Nutritional experiments were carried out dealing with: (1) the utilization of sulphur compounds; (2) the action of different mineral salts and their interaction. The results showed that the species of Pythium used grew well at $28^{\circ}$ buffered with Sorensen's salt to give an initial $\mathrm{pH}$ of 6.5 and incubated for 13 days for Pythium afertile and 10 days for the remaining species. Acid conditions below $\mathrm{pH} \mathrm{5.0}$ and alkaline conditions above pH 8.0 were not tolerated. The best carbon and nitrogen sources are given. The best sulphur sources were $\mathrm{Na}_{2} \mathrm{~S}, \mathrm{Na}_{2} \mathrm{~S}_{2} \mathrm{O}_{5}, \mathrm{Na}_{2} \mathrm{SO}_{4} .10 \mathrm{H}_{2} \mathrm{O}$, $\mathrm{Na}_{2} \mathrm{SO}_{3} .7 \mathrm{H}_{2} \mathrm{O}, \mathrm{Na}_{2} \mathrm{~S}_{2} \mathrm{O}_{5} .5 \mathrm{H}_{2} \mathrm{O}, \mathrm{K}_{2} \mathrm{~S}_{2} \mathrm{O}_{8}$, molecular sulphur, DL-methionine, thioacetamide, L-cysteine, sodium thioglycolate, and DL-cystine Factorial experiments were carried out in which the fungi were incubated at $28^{\circ}$ for 13-14 days. Statistical analysis of the results showed that under the given conditions optimal growth measured as mg. dry wt. was obtained in liquid media containing glucose, $10.0 \mathrm{~g}$./1.; $\mathrm{KCl}, 0.5 \mathrm{~g}$./1.; with varying amounts of $\mathrm{K}_{2} \mathrm{HPO}_{4}, \mathrm{KNO}_{3}$ and $\mathrm{MgSO}_{4} .7 \mathrm{H}_{2} \mathrm{O}$ for the different species specified. There was a balance between $\mathrm{K}_{2} \mathrm{HPO}_{4}$ and $\mathrm{MgSO}_{4} \cdot 7 \mathrm{H}_{2} \mathrm{O}$ for $P$. debaryanum and there were significant interactions between the salts above taken two at a time for $\boldsymbol{P}$. debaryanum and $\boldsymbol{P}$. ultimum but the interactions for the remaining fungi were more variable. There was interaction between all three salts together for two of the species. $P$. debaryanum is more exacting in its nutritional requirements than the other species.
\end{abstract}

Some species of Pythium are purely saprophytic, others are normally parasitic but may be saprophytic. Thus Pythium would seem to be a good genus for comparative nutritional studies. Previous work at Newcastle upon Tyne (see Fothergill et al.) indicated that for some parasitic fungi the balance of the major inorganic salts in a culture medium was more important for the good growth of the mycelium than the concentration of individual salts, but in the case of some saprophytic species, the balance of salts was much less important. Results, however, over a range of fungi varied. The present experiments are a continuation of work designed to investigate these points. Excluding work done on Pythium as a plant pathogen, a few physiological investigations have been reported mainly dealing with the presence and function of pectinase in these fungi (Chona, 1932; Menon, 1934; Fernando, 1937; Ashour, 1954; Damle, 1952; Gupta, 1956; Wood \& Gupta, 1958). The carbon, nitrogen, sulphur and vitamin requirements were investigated by Saksena (1942), Saksena \& Mehrota (1949), and Saksena, Jain \& Jaffri (1952), but Cantino (1955) 
strongly criticized these works because of the lack of $\mathrm{pH}$ control during the experiments. No comprehensive nutritional investigation has yet been carried out on Pythium.

\section{METHODS}

The following organisms were used. Pythium debaryanum Hesse originally isolated from Lepidium sp., $\boldsymbol{P}$. ultimum Trow from Pisum sativum L., $\boldsymbol{P}$. afertile Kanouse \& Humphrey and $\boldsymbol{P}$. torulosum Coker \& Patterson. All organisms were obtained from the Centraal Bureau voor Schimmelculture, Baarn. The first two species are parasites causing damping-off disease of seedlings, while the last two species are normally saprophytic soil fungi but they have been reported as growing on Gramineae (Middleton, 1943). Throughout this paper the following abbreviations are used: $\boldsymbol{P}$. debaryanum is designated $\mathrm{D} ; \boldsymbol{P}$. ultimum, $\mathrm{U} ; \boldsymbol{P}$. afertile, $\mathbf{A}$ and $\boldsymbol{P}$. torulosum, $\mathrm{T}$.

Initially single tip isolates were used as inocula for each species on Difco potatoextract-glucose agar medium. Stock cultures were kept on slopes of this medium in 6 in. $\times \frac{3}{4}$ in. test tubes and the cultures were stored at room temperature because Church \& Scandiffio (1928) showed that cultures of Pythium live longer at room than at lower temperatures. Subcultures were made as required. No alteration of morphological and cultural characteristics of these fungi occurred during the period of the experiments. In all experiments cultures were grown in $30 \mathrm{ml}$. aliquots in $150 \mathrm{ml}$. Erlenmeyer flasks. After the growth period the mycelia were filtered on to tared Whatman no. 5 filter-papers and washed with distilled water. The mycelium with the filter-papers was then dried for $24 \mathrm{hr}$. at $85^{\circ}$, cooled in a desiccator and weighed; results are expressed as mg. dry wt. mycelium/flask average of 4 or 5 replicates. It was not found practicable to separate mycelium from filter-paper after filtration and as the filter-papers used lose $5 \%$ of their original weight on drying under the above conditions, appropriate allowance was made for this. For preliminary experiments the following basal defined liquid medium $\mathbf{A}$ was used: glucose, 10 g.; $\mathrm{NH}_{4} \mathrm{NO}_{3}, 1.0 \mathrm{~g}$; $\mathrm{MgSO}_{4} .7 \mathrm{H}_{2} \mathrm{O}, 0.5 \mathrm{~g}$.; $\mathrm{KCl}, 0.5 \mathrm{~g}$; ; water to $1 \mathrm{l}$. This medium was buffered with Sorensen's phosphate buffer $\left(\mathrm{KH}_{2} \mathbf{P O}_{4}+\mathrm{NaHPO}_{4}\right)$ to give an initial pH of 6.5. Experiments showed that all the Pythium sp. grew well at this $\mathrm{pH}$ value. The parasitic species tolerated acid conditions, even at $\mathrm{pH} \mathbf{5} \cdot \mathbf{0}$, better than the saprophytic species which gave very low mycelial yields at this $\mathrm{pH}$ level. None of the species would grow at $\mathrm{pH} 8 \cdot 0$.

Experiments were carried out to determine the best method of inoculation and it was found that agar disks gave the most consistent mycelial dry weights provided the disks were between 3 and $8 \mathrm{~mm}$. in diameter. Disks of $4 \mathrm{~mm}$. diameter cut from the edge of $48 \mathrm{hr}$. old cultures were used in all later experiments. Experiments also showed that $4 \mathrm{~mm}$. disks did not significantly affect the nutritional results, that is, the nutritional effect of the Difco agar could be discounted and this was true also for the vitamins which may have been present in the agar. This latter point was tested for the presence of thiamin in the agar. Pythium vexans needs an exogenous supply of thiamin for growth (see Leonian \& Lilly, 1945). This fungus was tested in $(a)$ the basal medium alone, and in $(b)$ the basal medium plus thiamin using agar inocula. The average weight of 5 replicates showed that in $(a)$ growth was slight, but in (b) $71 \mathrm{mg}$. mycelium/flask were obtained. Further, the successful use of the agar 
disk method in the determination of vitamin requirements of other Pythium spp. was shown by Leonian \& Lilly (1939) and Saksena (1942). Addition or omission of the usual trace elements, $\mathrm{Fe}, \mathrm{Mn}$ and $\mathrm{Zn}$ made no difference to mycelial dry weights and these may be present in sufficient quantities in the Analar reagents used throughout. Tests also showed that none of the fungi needed an exogenous supply of biotin, nicotinic acid, folic acid, sodium pantothenate, pyridoxine, riboflavin, para-aminobenzoic acid or ascorbic acid. Neither thiamin nor its moieties affected growth, which supports the findings of Verma (1944). Robbins \& Kavanagh (1938), however, showed that $\boldsymbol{P}$. butleri needed an external supply of this vitamin. The optimum temperature for mycelial growth was $28^{\circ}$ but organism $\mathrm{T}$ had a rather slower growth rate than the other species. Optimum growth was reached after 13 days incubation for organism $A$ and after 10 days for organisms $D, U$ and $T$ on basal medium $\mathbf{A}$, and it was noted that in these preliminary experiments the mycelial yields of the parasites $D$ and $U$ were about twice those of the saprophytes $A$ and T. Experiments on the effect on mycelial growth of autoclaving the medium were carried out in which the composition of basal medium $\mathbf{A}$ was varied by substituting $\left(\mathrm{NH}_{4}\right)_{2} \mathrm{SO}_{4}$ and asparagine respectively for $\mathrm{NH}_{4} \mathrm{NO}_{3}$ using $\mathrm{U}$ as the test organism. Autoclaving these media at $10 \mathrm{lb}$. pressure for $5 \mathrm{~min}$. had no effect on the dry weight yields of this fungus but for periods above $15 \mathrm{~min}$. dry weight was seriously reduced. Hence all media were subsequently autoclaved at $10 \mathrm{lb}$. pressure for $5 \mathrm{~min}$.

\section{RESULTS}

\section{Sulphur requirements}

Preliminary experiments showed that all four isolates grew only slightly without sulphur in medium A. The sulphur requirement was then investigated by varying the sulphur source in this medium to give $0.5 \mathrm{~g}$./1. sulphur and in which $\mathrm{MgSO}_{4}$. $7 \mathrm{H}_{2} \mathrm{O}$ was omitted and $\mathrm{KCl}$ was replaced by $0.5 \mathrm{~g}$. $/ 1$. $\mathrm{MgCl}_{2}$. The final $\mathrm{pH}$ after autoclaving was between $6 \cdot 5$ and $6 \cdot 6$. The media were inoculated and then incubated at $28^{\circ}$. Dry weights of 4 replicate cultures were determined in all cases after 6,9 and 15 days incubation. The final $\mathrm{pH}$ of the media were also determined. The results are shown in Table 1 which records the highest percentage yields expressed in terms of the yield from $\mathrm{Na}_{2} \mathrm{SO}_{4} .10 \mathrm{H}_{2} \mathrm{O}$ as $100 \%$ for the inorganic sulphur sources and from DL-methionine as $100 \%$ for the organic sulphur sources. With $\mathrm{Na}_{2} \mathrm{SO}_{4} \cdot 10 \mathrm{H}_{2} \mathrm{O}$ the actual highest yields were $88 \mathrm{mg}$. for organism $\mathrm{D}, 92 \mathrm{mg}$. for $\mathrm{U}, 78 \mathrm{mg}$. for $A$ and $61 \mathrm{mg}$. for $\mathrm{T}$, all after 9 days incubation, while with DL-methionine the corresponding highest yields were 78 (after 6 days), 87, 73 and $49 \mathrm{mg}$. The last three were all after 9 days incubation. In all cases, except two, with inorganic sources of sulphur the highest yields were obtained after 9 days incubation but with organic sulphur sources the highest dry weights varied with the organism and the incubation period.

For the inorganic sulphur sources all the compounds used, except sodium dithionate and ammonium sulphamate, gave good or satisfactory growth with all the fungi, but organism A only gave a moderate yield with molecular sulphur. These Pythium species are, therefore, euthiotropic (Volkonsky, 1933). Increasing the oxidation level of the sulphur atom had no significant effect on mycelial growth. Thus molecular sulphur (S), a thiosulphate $\left(\mathrm{S}_{2} \mathrm{O}_{3}{ }^{2-}\right)$, a metabisulphite $\left(\mathrm{S}_{2} \mathrm{O}_{5}{ }^{2-}\right)$, 
a sulphite $\left(\mathrm{SO}_{3}{ }^{2-}\right)$ and a sulphate $\left(\mathrm{SO}_{4}{ }^{2-}\right)$ were all good sulphur sources for most of the species. Results using molecular sulphur, however, should be treated with caution. The results for the organic sulphur sources were more variable but, in general, the highest yields were obtained with DL-methionine, thioacetamide, L-cysteine (except for organism U), DL-cystine, sodium thioglycolate (except for organisms $\mathbf{A}$ and $\mathbf{T}$ ). The remaining compounds used gave only moderate or poor growth responses. Sulphanilic acid, DL-ethionine, thiocyanide, thioacetanilide and thiohydantoin were only utilized to a small extent.

Table 1. The utilization of inorganic and organic sulphur compounds by Pythium spp.

Highest yields expressed as percentage of yields from $\mathrm{A}, \mathrm{Na}_{2} \mathrm{SO}_{4} \cdot \mathrm{H}_{2} \mathrm{O}$, and $\mathrm{B}$, DLmethionine taken as 100. Final pH 6.2-6.6. (Mg. dry wt. mycelium/flask average of 4 replicates. 6 and 15 days incubation in brackets.)

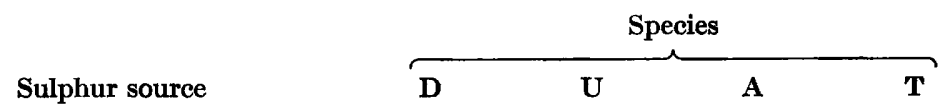

A. $\mathrm{Na}_{2} \mathrm{SO}_{4} \cdot 10 \mathrm{H}_{2} \mathrm{O}$ as $100 \%, 9$ days incubation

$\begin{array}{lrrrr}\text { Sodium sulphate } & 100 & 100 & 100 & 100 \\ \text { Sodium sulphide } & 102 & 90 & 79 & 67 \\ \text { Sodium metabisulphite } & 102 & 76 & 101 & - \\ \text { Sodium sulphite } & 98 & 84 & 103 & 92 \\ \text { Sodium thiosulphate } & 97 & 86 & 87 & 94 \\ \text { Sulphur } & 93 & 86 & 40(6) & 72 \\ \text { Potassium persulphate* } & 82 & 89 & 91 & 100 \\ \text { Sodium dithionate } & \mathbf{8 1} & \mathbf{3 5} & 8 & 18 \\ \text { Ammonium sulphamate } & 28(6) & 21 & 8 & 11\end{array}$

\begin{tabular}{|c|c|c|c|c|}
\hline DL-Methionine & $100(6)$ & $100(9)$ & $100(9)$ & 100 \\
\hline Thioacetamide & $100(15)$ & 100 & 57 & $63(15)$ \\
\hline L-Cysteine & 96 & 47 & 106 & $118(15)$ \\
\hline Sodium thioglycolate & $90(15)$ & 67 & 47 & 36 \\
\hline DL-Cystine & $85(6)$ & 98 & 97 & $84(15)$ \\
\hline Thiourea & 56 & $40(6)$ & 25 & $34(6)$ \\
\hline Thiamin & $58(15)$ & $54(15)$ & 28 & 38 \\
\hline Djenkolic acid & $56(15)$ & $48(15)$ & 31 (15) & 19 \\
\hline Taurine & $29(15)$ & $21(6)$ & $47(15)$ & $104(15)$ \\
\hline Sulphanilic acid & $22(6)$ & $24(6)$ & $11(6)$ & 10 \\
\hline DL-Ethionine & 17 & 8 & 10 & 8 \\
\hline Thiocyanide & 14 & 11 & 10 & $\mathbf{9}$ \\
\hline Thioacetanilide & $14(15)$ & $\mathbf{3 3}$ & $26(15)$ & $13(15)$ \\
\hline Thiohydantoin & 19 & 28 & 12 & 18 (15) \\
\hline None & 4 & 5 & 2 & 4 \\
\hline
\end{tabular}

The amino acids DL-methionine, DL-cystine, L-cysteine were very good sources for the species and in most cases these compounds were utilized more rapidly than any of the remaining compounds used. It may be that these compounds are absorbed and assimilated as intact molecules (see Steinberg, 1941). Djenkolic acid, also an amino acid, gave fair yields, but only after 15 days' incubation and it is worth noting that this compound is made up of two cysteine residues linked to a $\mathrm{CH}_{2}$ group through 
the sulphur atoms. Possibly djenkolic acid may have to be converted to cysteine before it is utilized. The poor utilization of thioacetanilide and sulphanilic acid supports Steinberg's conclusion (1941) that compounds containing sulphur attached to a benzene ring are unsuitable for use in assimilation by Aspergillus niger. Likewise thiohydantoin gave poor yields and it consists of a five-membered ring. DL-Ethionine was an extremely poor sulphur source for Pythium. Margolis \& Block (1957) also showed that five species of yeast could not utilize this compound, while Schlenk \& Tillotsen (1959) and Harris \& Cohn (1959) showed that ethionine is an antimetabolite of methionine.

\section{Factorial experiments}

The object of these experiments was to determine the effect of varying the concentration of the mineral salts in the basal medium. The factorial design and statistical analysis of the results should indicate whether or not a balance between the salts is necessary for high mycelial yields under the given experimental conditions. The direct effect of the individual salts in the medium and the interaction between them is also determined. Previous experiments showed that basal medium A was a satisfactory medium for the four Pythium spp., but as it contained $\mathrm{NH}_{4} \mathrm{NO}_{3}$ as the nitrogen source it required buffering with Sorensen's salt. Haskins $\&$ Weston (1950), using Karlingia rosea, showed that when $\mathrm{KNO}_{3}$ was used as a nitrogen source the $\mathrm{pH}$ of the culture medium remained approximately constant at pH 6.5 to 7.0. In the following experiments $\mathrm{KNO}_{3}$ was substituted for $\mathrm{NH}_{4} \mathrm{NO}_{3}$ and after preliminary experiments basal medium $\mathbf{B}$ was evolved containing glucose 10 g.; $\mathrm{KNO}_{3}, 2.0$ g.; $\mathrm{K}_{2} \mathrm{HPO}_{4}, 0.5$ g.; $\mathrm{MgSO}_{4} .7 \mathrm{H}_{2} \mathrm{O}, 0.5 \mathrm{~g} . ; \mathrm{KCl}, 0.5$ g.; distilled water to $1 \mathrm{l}$. The $\mathrm{pH}$ of this solution was adjusted to $6 \cdot 6$ with $0 \cdot 1 \mathrm{~N}-\mathrm{HCl}$. With this medium the $\mathrm{pH}$ value in the case of organisms $\mathrm{D}, \mathrm{U}$ and $\mathrm{T}$ never fell below 5.35, while with $A$ it never fell below 6.25. The cultures were incubated at $28^{\circ}$ for 14 days with organisms $\mathrm{D}$ and $\mathrm{T}$ and for 13 days with organisms $\mathrm{A}$ and $\mathrm{U}$. The concentrations of the salts were fixed on the basis of halving and doubling those in basal medium B. Thus $\mathrm{KNO}_{3}, \mathrm{MgSO}_{4} \cdot 7 \mathrm{H}_{2} \mathrm{O}$ and $\mathrm{K}_{2} \mathrm{HPO}_{4}$ were each used at three concentrations and all possible combinations of them were set up giving a total of 27 variations. Each combination was done in quadruplicate; thus with any one species of fungus 108 culture flasks were incubated. Each $150 \mathrm{ml}$. Erlenmeyer flask contained $30 \mathrm{ml}$. medium. The results are the average $\mathrm{mg}$. dry wt./mycelium of 4 replicates and the final $\mathrm{pH}$ values were determined in each case. The grouped results are shown in Table 2 and the grouped analyses of variance are given in Table 3. For abbreviations of the salt concentrations used in the text below see Table 2.

From the single salt analysis it is evident that there was no consistent result for all the organisms. This analysis showed that the differences between mycelial dry weights with $\mathrm{KNO}_{3}$ were significant for all concentrations of the salt for organisms $A$ and $D$. The highest mean weight for organism $A$ occurred at the $\mathbf{N}_{3}$ concentration and for organism $\mathrm{D}$ at the $\mathrm{N}_{1}$ level of $\mathrm{KNO}_{3}$. For organism $\mathrm{T}$ significance between the $N_{1}$ and $N_{3}$ levels occurred with the highest mean dry weight at the $N_{1}$ concentration of salt. For organism $U$ a significant difference occurred between the $\mathbf{N}_{1}$ and $N_{2}$ levels with the highest dry weight at the $\mathrm{N}_{2}$ concentration. At the $\mathrm{N}_{3}$ level of $\mathrm{KNO}_{3}$ with this organism there was a large decrease in mycelial dry wt. With $\mathrm{K}_{2} \mathrm{HPO}_{4}$ 
a significant difference was found between the $P_{1}$ and $P_{2}$ levels for organism $A$ with the highest dry weight at the $P_{2}$ level and between the $P_{1}$ and $P_{3}$ levels for organism $T$ with the highest dry weight at the $P_{2}$ level. For organisms $U$ and $D$ no significant differences in dry weights were found between any of the concentrations of $\mathrm{K}_{2} \mathrm{HPO}_{4}$ used, but for both organisms the highest dry weights occurred at the $\mathbf{P}_{\mathbf{3}}$ level of this salt. With $\mathrm{MgSO}_{4} \cdot 7 \mathrm{H}_{2} \mathrm{O}$ the only significant difference in mycelial dry weight was

Table 2. Growth responses of four species of Pythium to varying conditions of $\mathrm{K}_{2} \mathrm{HPO}_{4}, \mathrm{MgSO}_{4} \cdot 7 \mathrm{H}_{2} \mathrm{O}$ and $\mathrm{KNO}_{3}$

Concentration of $\mathrm{K}_{2} \mathrm{HPO}_{4}: \mathrm{P}_{1}, \mathrm{P}_{2}, \mathrm{P}_{3}=0.25,0.5,1.0 \mathrm{~g} / \mathrm{l}$; of $\mathrm{MgSO}_{4} .7 \mathrm{H}_{2} \mathrm{O}: \mathrm{Mg}_{1}, \mathrm{Mg}_{2}$, $\mathrm{Mg}_{3}=0.25,0.5,1.0 \mathrm{~g} . / \mathrm{l}$; of $\mathrm{KNO}_{3}: \mathrm{N}_{1}, \mathrm{~N}_{2}, \mathrm{~N}_{3}=1,2,4 \mathrm{~g} . / \mathrm{l}$. (Difference required between means for significance at odds of $99: 1$ for $\mathrm{KNO}_{3}, \mathrm{~K}_{2} \mathrm{HPO}_{4}$ and $\mathrm{MgSO}_{4} \cdot 7 \mathrm{H}_{2} \mathrm{O}=$ $5.3 \mathrm{mg}$. for $A$ and $T, 6.2 \mathrm{mg}$. for $U$ and $6.8 \mathrm{mg}$. for $D$ )

A. $\boldsymbol{P}$. debaryanum $(=\mathrm{D})$ and $\boldsymbol{P}$. ultimum $(=\mathrm{U})$

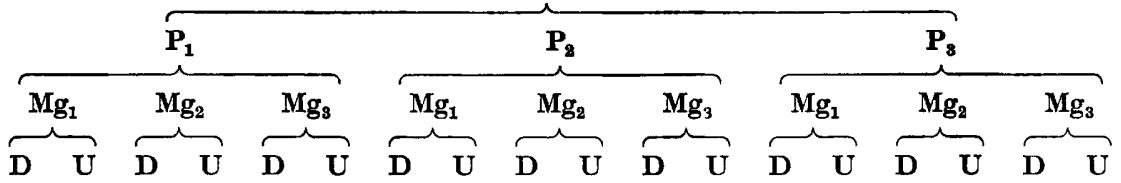

(Mean dry wt. mycelium mg./flask)

$\begin{array}{lllllllllllllllllll}N_{1} & 167 & 168 & 162 & 175 & 160 & 163 & 168 & 172 & 171 & 175 & 163 & 170 & 153 & 163 & 181 & 169 & 172 & 175\end{array}$

$\begin{array}{lllllllllllllllllll}\mathbf{N}_{2} & 131 & 181 & 146 & 185 & 133 & 182 & 133 & 181 & 142 & 182 & 161 & 158 & 136 & 180 & 136 & 185 & 161 & 172\end{array}$

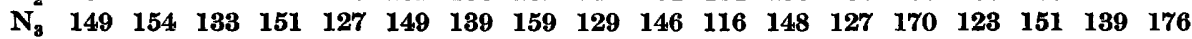

B. $P$. afertile $(=\mathrm{A})$ and $\boldsymbol{P}$. torulosum $(=\mathrm{T})$

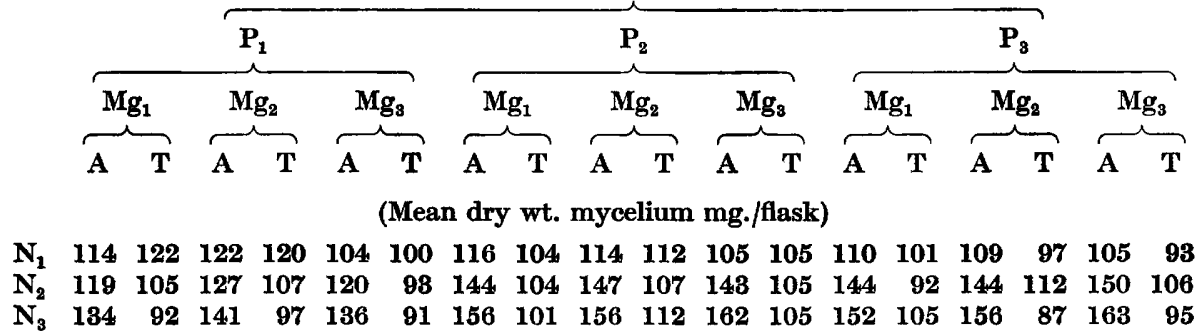

Table 3. Analysis of variance (grouped) for Pythium spp. A, T, U, D

Required ' $F$ ' and ' $t$ ' values taken from Snedecor's tables (1934). Sums of squares and mean squares are omitted from table.

$F$ required odds

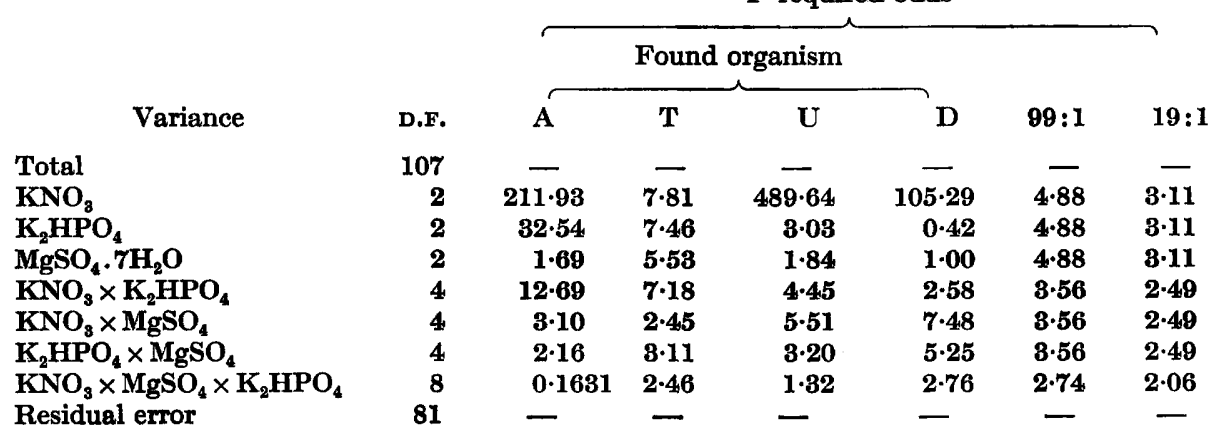


found for organism $\mathrm{T}$ between the $\mathrm{Mg}_{2}$ and $\mathrm{Mg}_{3}$ levels with the highest dry weight at the $\mathrm{Mg}_{2}$ concentration of the salt. For organisms $\mathbf{A}, \mathrm{U}$ and $\mathrm{D}$ there were no significant differences between any of the levels of the salt. But for $A$ the highest mean dry weight of mycelium was obtained at the $\mathrm{Mg}_{2}$ level, for $\mathrm{U}$ at the $\mathrm{Mg}_{1}$ level, and for $\mathrm{D}$ at the $\mathrm{Mg}_{3}$ level of concentration of $\mathrm{MgSO}_{4} \cdot 7 \mathrm{H}_{2} \mathrm{O}$.

\section{Balance between $\mathrm{K}_{2} \mathrm{HPO}_{4}$ and $\mathrm{MgSO}_{4} \cdot 7 \mathrm{H}_{2} \mathrm{O}$}

The grouped analyses of variance showed that there was a significant interaction between $\mathrm{K}_{2} \mathrm{HPO}_{4}$ and $\mathrm{MgSO}_{4} \cdot 7 \mathrm{H}_{2} \mathrm{O}$ only for the parasitic organism $\mathrm{D}$. This result also indicated that there was a physiological balance between these salts under the conditions of the experiments. Talley \& Blank (1941) and Fothergill \& Ashcroft (1955) have also shown that a physiological balance exists between these two salts and is important for the good growth of Phymatotrichum omnivorum and Venturia inaequalis. To confirm this result another experiment was designed to test the change in the amount of growth which might result when the concentrations of the salts were varied while still maintaining the balance between them. Thus the basic concentration of $\mathrm{K}_{2} \mathrm{HPO}_{4}$ and $\mathrm{MgSO}_{4} .7 \mathrm{H}_{2} \mathrm{O}$ was $0.5 \mathrm{~g}$. $/ 1$. and $0.25 \mathrm{~g}$./l. respectively; these concentrations were decreased to half in one set of solutions and increased twice and then 4 times in other solutions. This gave four treatments, each one having the same balance between the salts but the ratio of their concentrations was $0 \cdot 5: 1: 2: 4$. Each of these treatments was tested singly with $0.5,1 \cdot 0,2 \cdot 0$ and $4.0 \mathrm{~g}$./ 1 . of $\mathrm{KNO}_{3}$. The remaining ingredients of basal medium $\mathrm{B}$ remained constant. The initial $\mathrm{pH}$ of the media was adjusted to 6.5 prior to autoclaving and the cultures were incubated in 5 replicates at $28^{\circ}$ for 14 days. The results expressed as mg. mean dry wt./mycelium are shown in Table 4, where treatments are numbered 1 to 16 in brackets.

Table 4. Mean dry weights and growth responses of Pythium debaryanum after 14 days incubation at $28^{\circ}$ on media with the same balance but with different concentrations of certain components

Concentrations of salts as in Table 2 with following additions: $\mathrm{K}_{2} \mathrm{HPO}_{4}: \mathrm{P}_{4}=\mathbf{2 - 0} \mathrm{g}$. $/ \mathrm{l}$; $\mathrm{MgSO}_{4} \cdot 7 \mathrm{H}_{2} \mathrm{O}: \mathrm{Mg}_{0}=0.125 \mathrm{~g}$. $/ 1$; $\mathrm{KNO}_{3}: \mathrm{N}_{0}=0.5 \mathrm{~g}$. $/$. (The sixteen different solutions numbered in parentheses are referred to in the text as treatments 1 to 16).

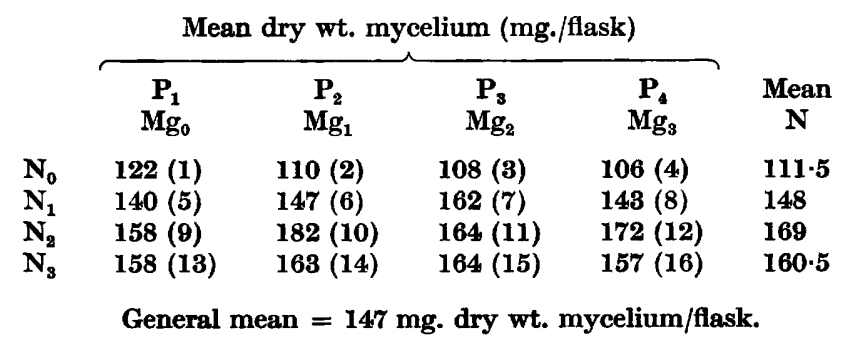

The results showed that the mycelial yields for $\mathrm{KNO}_{3}$ at $\mathrm{N}_{0}$ and $\mathrm{N}_{1}$ levels were significantly different from each other and from the $\mathrm{P}_{2}$ and $\mathrm{N}_{3}$ levels but these latter two levels were not different. To show the interaction of $\mathrm{K}_{2} \mathrm{HPO}_{4}$ and $\mathrm{MgSO}_{4} \cdot 7 \mathrm{H}_{2} \mathrm{O}$ ' $~ t$ ' tests were performed. There were no significant differences between: $(a)$ treatments 2,3 and 4 at the $\mathrm{N}_{0}$ level of $\mathrm{KNO}_{3} ;(b)$ treatments $5,6,7$ and 8 at the $\mathrm{N}_{1}$ level 
of $\mathrm{KNO}_{3} ;(c)$ treatments 10,11 and 12 at the $\mathrm{N}_{2}$ level; and $(d)$ treatments $13,14,15$ and 16 at the $\mathrm{N}_{3}$ level. While there were significant differences between treatments 1 and 2 at the $\mathrm{N}_{0}$ level of $\mathrm{KNO}_{3}$ and treatments 9 and 10 at the $\mathrm{N}_{2}$ level, this lack of significant differences at the respective levels of $\mathbf{N}$ confirms the conclusion that a balance exists between $\mathrm{K}_{2} \mathrm{HPO}_{4}$ and $\mathrm{MgSO}_{4} \cdot 7 \mathrm{H}_{2} \mathrm{O}$ and that the concentration of either of these salts can be varied over a wide range without affecting mycelial yields providing that the concentrations of the other salts are varied in proportion. The significance obtained with treatments 1 and 9 at the lowest concentration of salts may indicate that the balance necessary for good growth only comes into operation above a certain minimum concentration of salts. A similar effect with Venturia inaequalis was noticed by Fothergill \& Ashcroft (1955).

\section{CONCLUSION}

The analyses of variance also showed the first- and second-order interactions between the salts in the medium, and indicated some of the nutritional differences between the fungi investigated. For the fungi $D$ and $U$ all the first-order interactions (i.e. the interactions of all the salts taken two at a time) were significant at either the 99:1 or 19:1 level of odds. For the fungi $A$ and $T$ the results were more varied. For organism $A$ the interaction of $\mathrm{KNO}_{3} \times \mathrm{K}_{2} \mathrm{HPO}_{4}$ and $\mathrm{KNO}_{3} \times \mathrm{MgSO}_{4}$. $\boldsymbol{7}_{2} \mathrm{O}$ were significant but not that between $\mathrm{K}_{2} \mathrm{HPO}_{4} \times \mathrm{MgSO}_{4} \cdot \mathbf{7 H}_{2} \mathrm{O}$, while for organism $\mathrm{T}$ the interactions $\mathrm{KNO}_{3} \times \mathrm{K}_{2} \mathrm{HPO}_{4}$ and $\mathrm{K}_{2} \mathrm{HPO}_{4} \times \mathrm{MgSO}_{4} \cdot 7 \mathrm{H}_{2} \mathrm{O}$ were significant but not that between $\mathrm{KNO}_{3} \times \mathrm{MgSO}_{4} \cdot 7 \mathrm{H}_{2} \mathrm{O}$. In the second-order interactions only those for organisms $\mathbf{D}$ and $\mathrm{T}$ were significant.

In general the results of the factorial experiments showed that there was a considerable difference between the nutritional requirements of Pythium debaryanum (D) and $\boldsymbol{P}$. ultimum (U). With the individual salts the greatest effect was produced by varying the concentration of $\mathrm{KNO}_{3}$. An absolute balance between all the nutrients was required by $\boldsymbol{P}$. debaryanum (D) for good mycelial growth, but was not so necessary for $\boldsymbol{P}$. ultimum (U). With the species, $\boldsymbol{P}$. afertile (A) and $\boldsymbol{P}$.torulosum (T) variation in the concentration of most of the individual salts produced large effects on mycelial growth and at the highest level of probability the interaction with $\mathrm{KNO}_{3}$ was significant. Kitchell (1954), Fothergill \& Yeoman (1957), and Fothergill $\&$ Jones (1958) also found that the concentration of the nitrogen sources and the interaction between these and the phosphorus source had a significant effect on the growth of Mucor spp., Rhizopus stolonifera and Zygorhynchus spp., all saprophytes. These results also support the findings of Fothergill \& Jones (1958) who showed that there was a variation of balance in salt concentrations for different Zygorhynchus spp. Although each Pythium spp. has its own nutritional requirements $\mathrm{D}$ and $\mathrm{U}$ in general needed a more exact balance of mineral salts and showed less variation in their response to individual salts than did $\mathbf{A}$ and $\mathrm{T}$ here investigated. Differences in nutritional requirements between these fungi are statistically significant but they are not very large. 


\section{REFERENCES}

Ashour, W. E. (1954). Pectinase production by Botrytis cinerea and Pythium debaryanum. Trans. Brit. mycol. Soc. 37, 343.

Cantino, E. C. (1955). Physiology and phylogeny in the water moulds. Quart. Rev. Biol. 30, 138.

Chona, B. L. (1932). Studies in the physiology of parasitism. XIII. Ann. Bot., Lond. 46, 1033.

Church, M. M. \& Scandiffio, M. (1928). Phytophthora, Pythium and Pythiacystis species in stock culture. Phytopathology, 18, 247.

DamLe, V. D. (1952). Enzymic studies of certain parasitic fungi. J. Indian bot. Soc. 31, 13.

Fernando, M. (1937). Studies in the physiology of parasitism, XV. Ann. Bot., Lond. N.S., $1,727$.

Fothergili, P. G. \& Ashcroft, R. (1955a). The nutritional requirements of Venturia inaequalis. J. gen. Microbiol. 12, 387.

Fothergill, P. G. \& Ashcroft, R. $(1955 b)$. Further nutritional studies of Venturia inaequalis. J. gen. Microbiol. 13, 399.

Fothergill, P. G. \& Jones, M. (1958). Nutritional studies of some Zygorhynchus species. J. gen. Microbiol. 19, 298.

Fothergill, P. G. \& Raine, L. C. D. P. (1954). The mineral nutritional requirements of Mucor hiemalis Wehm. J. gen. Microbiol. 10, 17.

Fothergill, P. G. \& Yeoman, M. M. (1957). The mineral nutrition of Rhizopus stolonifera. J. gen. Microbiol. 17, 631.

Gupta, S. C. (1956). Studies in the physiology of parasitism. XIII. Ann. Bot., Lond. 20, 179.

Harris, J. \& Cohn, H. (1959). In Aspects of the Organic Chemistry of Sulphur. London: F. Challenger.

Haskins, R. H. \& Weston, W. H., Jun. (1950). Studies in the lower Chytridiales. 1. Factors affecting pigmentation, growth and metabolism of a strain of Karlingia (Rhizophyctis) rosea. Amer. J. Bot. 37, 739.

KITCHELL, A. G. (1954). The utilization of inorganic and organic nitrogen compounds by Mucor spp. in relation to the carbohydrate requirements. Ph.D. Thesis, Durham University.

Leonian, L. H. \& Lilly, V. G. (1939). Studies in the nutrition of fungi. II. Effect of inoculum on the growth of the colony. Phytopathology, 31, 592.

LEONIAN, L. H. \& LiLLY, V. G. (1945). The comparative value of different test organisms in microbiological assays of B vitamins. Bull.W. Va. agric. Exp. Sta. no. 319.

Margolis, D. \& Block, R. G. (1957). Sulphur metabolism of yeast. 1. A study of relative growth of five yeasts on a sulphur-free medium supplemented with small quantities of sulphur compounds. Contrib. Boyce Thompson Inst. 19, 437.

Menon, K. P. V. (1934). Studies in the physiology of parasitism, XIV. Ann. Bot., Lond. 48, 187.

Middleton, J. T. (1943). Taxonomy, host range and geographical distribution of the genus Pythium. Mem. Torrey bot. Cl. No. 20.

Robbins, W. J. \& Kavanagh, F. (1938). Thiamin and the growth of Pythium butleri. Bull. Torrey bot. $\mathrm{Cl}$. 65, 453.

Saksena, R. K. (1942). Thiamin and growth of some species of Pythium. Proc. Indian Acad. Sci. B, 14, 141.

Saksena, R. K. \& Mehrotra, B. S. (1949). Carbon requirements of the genus Pythium. Proc. nat. Acad. Sci. India, 19, 1.

SAKSENA, R. K., JAIN, S. K. \& JAFFRI, S. M. H. (1952). Sulphur and nitrogen requirements of the genus Pythium. J. Indian bot. Soc. 31, 281.

Schlenk, F. \& Tillotsen, J. A. (1959). In Aspects of the Organic Chemistry of Sulphur. London: F. Challenger.

SNedecor, G. W. (1934). Statistical Methods, 4th ed. Iowa State College Press.

Steinberg, R. S. (1941). Sulphur and trace element nutrition of Aspergillus niger. J. agric. Res. 63, 109. 
Talley, P. J. \& Blank, L. M. (1941). A critical study of the nutritional requirements of Phymatotrichum omnivorum. Plant Physiol. 16, 1.

Verma, J. C. (1944). Studies on the genus Pythium. Thesis, Allahabad University, India. See Saksena \& Mehrotra, 1949.

Volkonsky, M. (1933). Sur l'assimilation des sulphates par les champignons. Ann. Inst. Pasteur, 50, 703.

Wood, R. K. S. \& GuPTA, S. C. (1958). Studies in the physiology of parasitism 25. Ann. Bot., Lond. N.S., 22, 309. 